\title{
PENGEDUKASIAN UMKM JEGEG BALI TAILOR MELALUI TRANSFORMASI DIGITAL SELAMA PANDEMI COVID-19 DI TABANAN- BALI
}

\author{
${ }^{1}$ Kadek Adi Wibawa, ${ }^{2}$ Ni Made Devi Mayanti \\ 1,2Universitas Maharaswati Denpasar, Bali, Indonesia \\ email:Iadiwibawa@unmas.ac.id, 2devimayanti306@gmail.com
}

\begin{abstract}
The existence of the Covid-19 pandemic requires people to comply with health protocols established by the government, such as wearing masks, social distancing, traveling outside the house only when there is an interest, and diligently washing their hands properly and using soap. The Covid-19 pandemic has economic, social and political implications not only for big countries but almost all countries in the world. Indonesia is one of the countries affected especially on the economic side. Indonesia which is dominated by Usaha Mikro Kecil Menengah (UMKM) needs to pay special attention to this sector because the contribution of UMKM to the National economy is quite large. The target of this community service is an UMKM that is engaged in the production of sewing women's kebaya and formal clothes. Based on the results of direct observations, there were problems faced by UMKM, namely the problem of lack of product promotion media and the absence of financial records at UMKM. Activities carried out include assisting the online promotion process by utilizing social media and e-commerce, creating logos and product packaging innovations, and making financial records for UMKM. In its implementation, activities are carried out online and offline. This community service activity is expected to help UMKM in the economic sector due to the impact caused by Covid19.

Keywords: The impact of Covid-19, UMKM, online promotions, and product innovation
\end{abstract}

\begin{abstract}
Abstrak. Adanya pandemi Covid-19 mewajibkan masyarakat mematuhi protokol kesehatan yang ditetapkan oleh pemerintah, seperti memakai masker, menjaga jarak atau social distancing, bepergian keluar rumah hanya saat ada kepentingan, dan rajin mencuci tangan dengan benar dan menggunakan sabun. Pandemi Covid-19 memberikan implikasi ekonomi, sosial, dan politik tidak saja pada negara-negara besar akan tetapi hampir seluruh negara di dunia. Indonesia adalah salah satu negara yang terdampak terutama pada sisi ekonomi. Indonesia yang didominasi oleh Usaha Mikro, Kecil, dan Menengah (UMKM) perlu memberikan perhatian khusus terhadap sektor ini karena kontribusi UMKM terhadap perekonomian Nasional yang cukup besar. Sasaran pengabdian pada masyarakat ini merupakan sebuah UMKM yang bergerak dibidang produksi menjahit kebaya wanita dan pakaian formal. Berdasarkan hasil observasi yang dilakukan secara langsung, ditemukan permasalahan yang dihadapi UMKM ini, yaitu masalah kurangnya media promosi produk dan tidak adanya catatan keuangan pada UMKM. Kegiatan yang dilakukan adalah membantu proses promosi secara online dengan memanfaatkan media sosial dan e-commerce, pembuatan logo dan inovasi kemasan produk, serta pembuatan catatan keuangan untuk UMKM. Dalam pelaksanaannya kegiatan dilakukan secara online dan offline. Kegiatan pengabdian pada masyarakat ini diharapkan dapat membantu UMKM dalam bidang ekonomi akibat dampak yang disebabkan oleh Covid-19.
\end{abstract}

Kata Kunci: Dampak Covid-19, UMKM, promosi online, dan inovasi produk 


\section{Pendahuluan}

Sasaran masyarakat dalam pengabdian masyarakat ini adalah UMKM penjahit kebaya dan pakaian formal yang bernama Jegeg Bali Tailor, berlokasi di Banjar adat Denbantas Kecamatan Tabanan, Kabupaten Tabanan, Bali. Adanya pandemi Covid19 mewajibkan masyarakat mematuhi protokol kesehatan yang ditetapkan oleh pemerintah, seperti memakai masker, menjaga jarak atau social distancing, bepergian keluar rumah hanya saat ada kepentingan, dan rajin mencuci tangan dengan benar dan menggunakan sabun (Anang, S., dkk., 2020). Berdasarkan hasil observasi yang dilakukan secara langsung kepada masyarakat sasaran, ditemukan permasalahan yang dihadapi UMKM yaitu masalah kurangnya media promosi produk, UMKM belum memiliki logo dan kemasan produk, serta UMKM belum memiliki catatan keuangan.

Usaha menjahit ini telah didirikan Ibu Made Sudiartini selama 5 tahun dengan mempekerjakan 1 orang penjahit dan 1 orang pemasang kancing. Namun karena pandemi, usahanya semakin sepi diakibatkan pengguna kebaya ini dominan digunakan oleh wanita yang pergi ke pura untuk bersembahyang atau kebaya yang dibuat untuk acara kundangan, namun karena adanya pandemi selain mengakibatkan lemahnya ekonomi, hal ini mengakibatkan menurunnya kegiatan produksi dari UMKM sasaran.

Contohnya acara kundangan semakin diperketat tidak boleh mengundang banyak orang, begitu juga dengan kegiatan persembahyangan di pura kegiatan untuk bekumpul dengan jumlah orang dibatasi sebagai upaya pemutusan rantai penyebaran virus Covid-19. Oleh karena itu UMKM Bu Made menambah inovasi produknya berupa masker kain yang berbahan dasar kain katun, endek dan brokat dan berbagai jenis masker kain yang dapat direquest oleh pelanggannya.

Kesempatan untuk melakukan promosi produk secara online tidak bisa dinikmati oleh semua pemilik bisnis, khususnya para UMKM yang belum memiliki literasi digital tinggi. Salah satunya di Banjar Adat Denbantas, mereka belum paham bagaimana konsep marketplace bekerja, pemasaran melalui layanan on-demand dan lainnya.

Melihat kondisi tersebut, pengabdian kepada masyarakat Universitas Mahasaraswati Denpasar hadir membawa misi untuk membantu UMKM melakukan digitalisasi. Caranya yaitu dengan membuatkan UMKM sasaran suatu media promosi online, logo usaha dengan inovasi kemasannya, dan catatan keuangan usaha dengan sentuhan teknologi. Dosen dan mahasiswa aktif berperan serta dalam pengedukasian dan pelatihan mengenai bagaimana cara pengoperasian dan membagi ilmu yang dimiliki bersama UMKM sasaran sebagai pengaplikasian pembelajaran pada saat perkuliahan.

Dalam melakukan pemasaran diperlukan strategi yang menyesuaikan dengan perkembangan zaman, yaitu pemasaran secara online melalui media sosial dan e-commerce serta memanfaatkan berbagai teknologi (Aarker, D., 2013). Promosi secara online dilakukan dengan membuat akun media sosial seperti facebook, instagram serta mendaftarkan UMKM pada pasar online atau e-commerce seperti Shoppe, Tokopedia dan Bukalapak. Dipilihnya akun media sosial dan e-commerce ini karena di Indonesia banyak pengguna yang memanfaatkan beberapa aplikasi yang disebutkan diatas untuk bertransaksi jual beli barang dengan kualitas yang dijamin, dapat melakukan pengiriman ke seluruh Indonesia serta dapat menampilkan foto dan video sehingga produk yang dipromosikan 
dapat dideskripsikan dengan baik dan sebagai konsumenpun dapat mengetahui setiap detail dari produk. Kegiatan dengan memanfaatkan sosial media dan e-commerce sudah banyak dilakukan oleh kelompok masyarakat untuk membantu UMKM dalam rangka meningkatkan produktifitas (Astuti, R.P., Kartono, \& Rahmadi, 2020; Permana, S.D.H. \& Cendana, M., 2019; dan Sukarsih, I., dkk., 2019).

Kemajuan teknologi dapat dimanfaatkan oleh UMKM sasaran untuk mempromosikan usahanya sehingga hal ini diharapkan dapat membantu UMKM sasaran dan UMKM lainnya untuk tetap dapat memasarkan produknya ke konsumen dan lebih mengenalkan produk lokal dengan kualitas yang baik (Pakpahan, A.K., 2020)

Pencatatan keuangan dalam suatu bisnis atau usaha merupakan hal yang sangat penting walau hanya dilakukan dengan sederhana, suatu arus kas pengeluaran dan pemasukan suatu usaha dapat dilihat dengan jelas sehingga dapat dijadikan acuan untuk meminimalkan pengeluaran yang dianggap dapat menghabiskan banyak biaya, serta dalam pendapatan hasil yang diperoleh usaha dapat dibedakan dengan pendapatan pribadi pemiliki UMKM.

Pemanfaatan teknologi dalam mencatat keuangan dapat digunakan, misalnya pada Windows terdapat Microsoft Excel yang berisi rumusrumus yang dapat disesuaiakan pengaplikasiannya mulai dari yang sederhana sampai dengan yang rumit untuk menjalankannya dibutuhkan pengetahuan untuk membuat catatan keuangan yang menyesuaikan kebutuhan UMKM, seperti akun apa yang digunakan, terutama untuk UMKM sasaran yang merupakan usaha bidang jasa.

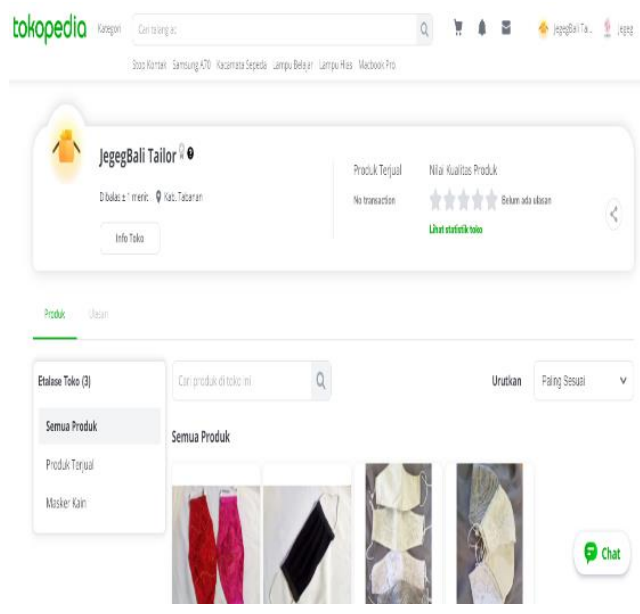

Gambar 1. Produk masker kain UMKM Jegeg Bali Tailor dipromosikan melalui e-commerce Tokopedia.

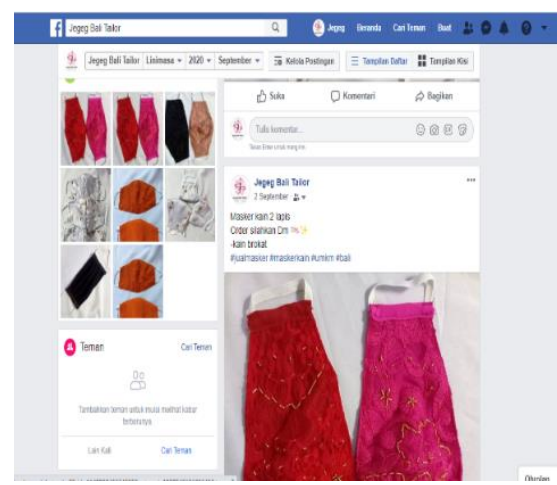

Gambar 2. Produk masker kain UMKM Jegeg Bali Tailor dipromosikan melalui sosial media facebook.

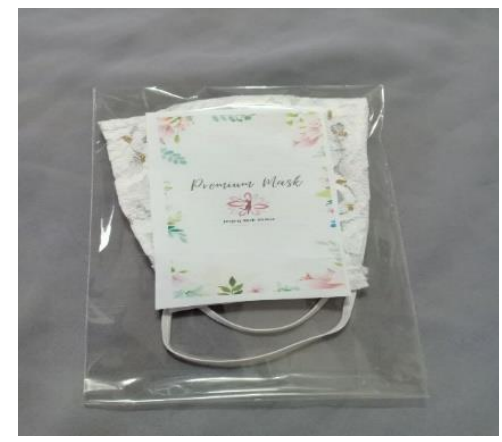

Gambar 3. Inovasi kemasan produk masker kain yang sudah dilengkapi dengan logo UMKM. 


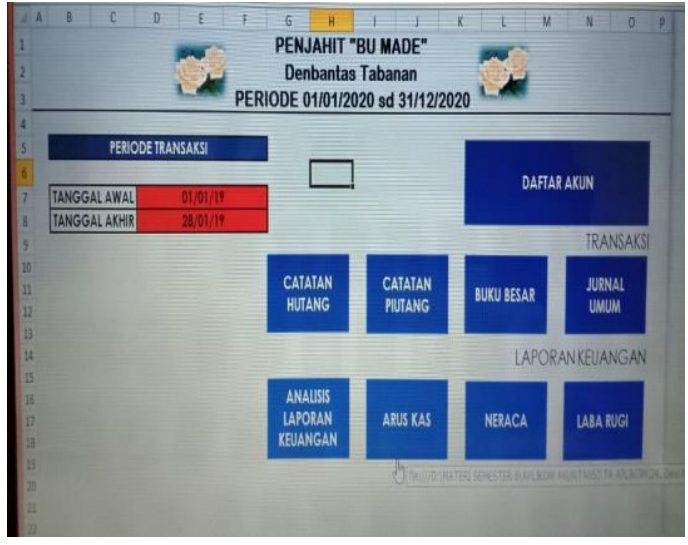

Gambar 4. Catatan keuangan UMKM Jegeg Bali Tailor dengan memanfaatkan Microsoft Excel.

Rumusan masalah dari pengabdian masyarakat ini adalah 1) Pengenalan serta pelatihan media sosial dan e-commerce kepada masyarakat sasaran untuk meningkatkan pemasaran dan nilai penjualan, 2) Pembuatan logo usaha dan inovasi kemasan produk yang dihasilkan masyarakat sasaran guna menambah nilai estetika pada produk, dan 3) Pelatihan pembukuan sederhana yang simpel dengan sentuhan teknologi guna mengefektifkan kinerja UMKM pada aspek manajerial.

Solusi dan target yang ingin dicapai adalah 1) membuat akun promosi dan memberikan pelatihan kepada mitra cara untuk mempromosikan produk melalui pasar online, seperti shoppe, bukalapak dan tokopedia, memperomosikan melalui media sosial seperti Facebook dan Instagram, 2) Membuat logo usaha dan kemasan produk yang sesuai dan menggambarkan usaha UMKM ini. Sifat program ini adalah rintisan dan 3) Memberikan pelatihan kepada mitra bagaimana membuat pembukuan sederhana secara platform catatan keuangan harian dengan Microsoft Excel. Sifat program ini adalah rintisan.

\section{Metode}

Dalam kegiatan kali ini Pengabdian Masyarakat Universitas
Mahasaraswati Denpasar yang diprakarsai oleh Kadek Adi Wibawa sebagai penanggung jawab kegiatan, $\mathrm{Ni}$ Made Devi Mayanti sebagai pelaksana tugas melakukan promosi UMKM yang ada di Banjar Adat Denbantas dengan transformasi digital berupa program kerja yaitu pada bidang teknologi dan manajerial. Pelaksanaan program kerja dalam rangka memberikan solusi atas permasalahan yang dihadapi mitra menggunakan Difusi Ipteks melalui pelatihan akun media sosial dan $e$ commerce, serta Entrepreneurship Capacity Building melalui pelatihan mempromosikan produk secara online, pembuatan logo usaha dan inovasi kemasan produk serta pelatihan tentang pembukuan sederhana UMKM dengan pemanfaatan aplikasi Microsoft Excel.

\section{Hasil dan Pembahasan}

Salah satu UMKM sasaran dari kegiatan pengabdian pada masyarakat ini adalah UMKM penjahit kebaya, Jegeg Bali Tailor yang berlokasi di Banjar Adat Denbantas Tabanan. Selain memproduksi kebaya UMKM ini juga mengembangkan usahanya dengan memproduksi masker kain yang berbahan dasar kain endek, katun dan brokat sebagai upaya inovasi produk pada masa pandemi akibat Covid-19. Melihat usaha UMKM ini perlu membutuhkan media promosi yang lebih luas agar produk yang dihasilkan dapat dipasarkan tidak hanya dilingkungan sekitar lokasi UMKM, selain itu diperlukan logo usaha dan kemasan produk yang menggambarkan UMKM ini, serta UMKM sasaran membutuhkan suatu catatan keuangan khusus untuk mengetahui setiap arus kas masuk dan keluar usaha.

Maka tim pelaksana tugas pengabdian masyarakat Universitas Mahasaraswati Denpasar memperkenalkan kepada pemilik usaha tersebut 
promosi produk secara online, pembuatan logo usaha dan inovasi kemasan produk, serta catatan keuangan dengan pemanfaatan teknologi.

Pemilik UMKM merespon kegiatan promosi online tersebut dengan sangat baik. Untuk promosi usahanya, pengabdi telah membuat akun media khusus seperti Instagram, dan Facebook serta telah mendaftarkan UMKM pada e-commerce seperti Tokopedia, Shoppe, dan Bukalapak sebagai media UMKM dalam mempromoikan produknya.

Dengan memanfaatkan media sosial dan e-commerce UMKM dapat mempromosikan produknya sehingga diharapkan dapat meningkatkan penjualan dan dengan adanya inovasi logo usaha yang telah ditambahkan pada kemasan produk. Sama halnya dengan pemanfaatan teknologi saat pembuatan catatan keuangan diharapkan dapat mengefektifkan kinerja UMKM.

Hasil dari pengedukasian dan pelatihan kegiatan pengabdian pada masyarakat ini yaitu UMKM dapat memaksimalkan usahanya dengan memanfaatkan teknologi. UMKM diharapkan mampu mengaplikasikan teknologi yang telah diberikan kepada UMKM untuk mempermudah pemasaran produk, sehingga produk lokal tetap memiliki nilai jual dengan kualitas yang tidak kalah bersaing dengan produk impor.

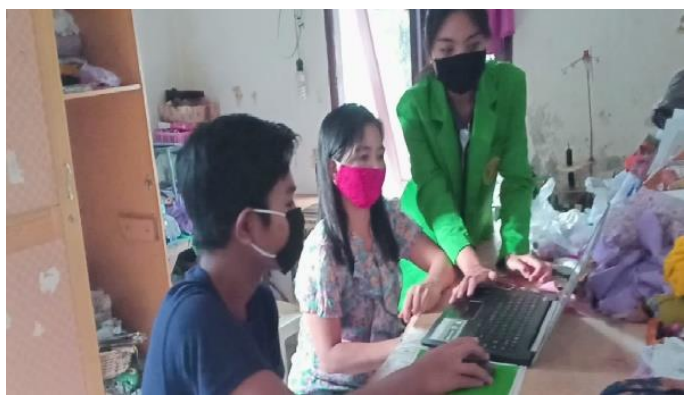

Gambar 1. Mahasiswa Universitas

Mahasaraswati Denpasar Sedang menjelaskan cara menggunakan dan mempromosikan produk pada media sosial dan e-commerce kepada pemilik

UMKM di Banjar Adat Denbantas.

Setelah mahasiswa menjelaskan bagaimana cara mengunggah produk pada media promosi, pemilik UMKM selanjutnya dapat mempromosikan lebih banyak produk dengan mencantumkan harga dan penjelasan lebih lengkap pada produk yang dipromosikan. Hasilnya adalah pelaku UMKM bisa mengaplikasikan media promosi dengan baik biarpun para pelaku UMKM masih agak kebingungan dalam mengoperasikannya.

Untuk lebih mengenalkan usaha UMKM diperlukan logo usaha serta inovasi kemasan produk untuk menambah nilai estetika produk. Dengan hal ini pemilik UMKM bersedia untuk bersaa-sama membuat inovasi yang lebih baik untuk produk.

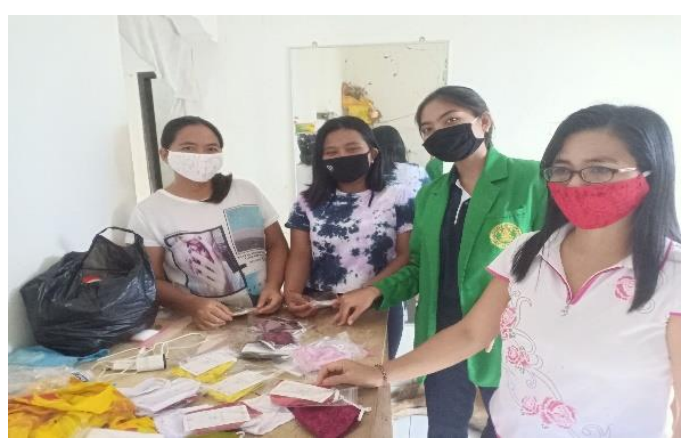

Gambar 2. Mahasiswa Universitas Mahasaraswati Denpasar bersama UMKM Jegeg Bali Tailor memberikan inovasi kemasan produk yang telah dilengkapi dengan logo usaha.

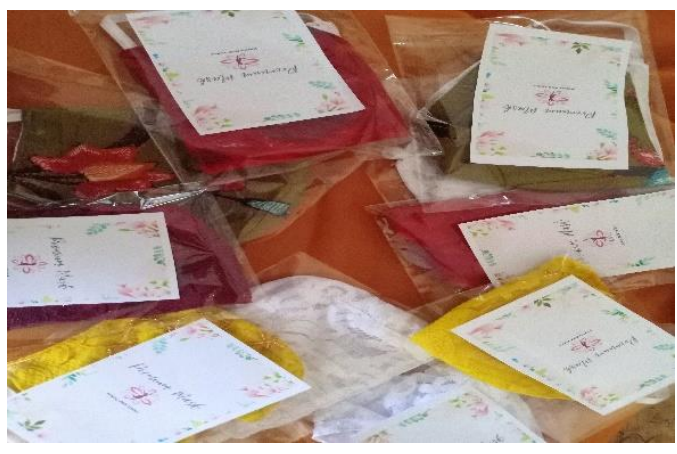

Gambar 3. Produk masker kain yang telah dikemas dan siap dipasarkan kepada konsumen. 
Pembuatan catatan keuangan dengan pemanfaatan Microsoft Excel untuk membantu pencatatan keuangan UMKM sehingga arus kas masuk dan keluar yang telah terjadi dalam suatu periode dapat diketahui dengan jelas.

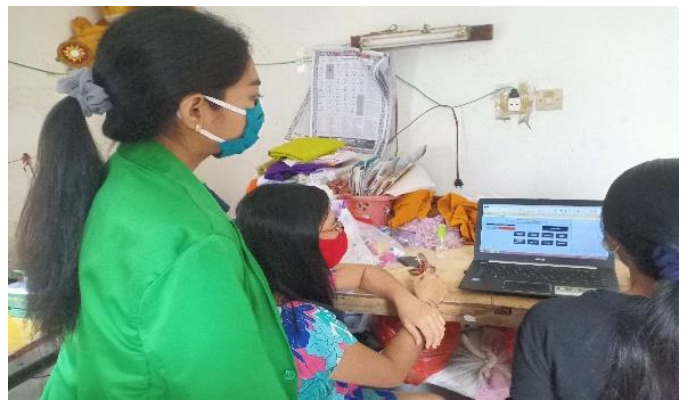

Gambar 4. Mahasiswa Universitas Mahasaraswati Denpasar Sedang menjelaskan cara penggunaan catatan keuangan dengan pemanfaatan teknologi kepada pemilik UMKM di Banjar Adat Denbantas.

Maka pelaksanaan program kegiatan Pengedukasian UMKM dengan transformasi digital dalam rangka pertahanan ekonomi di tengah pandemi Covid-19 telah berhasil dilaksanakan melalui observasi, penyuluhan, dan pelatihan.

\section{Kesimpulan dan Saran}

Salah satu cara promosi adalah dengan promosi melalui media digital. Jenis promosi melalui media digital mencakup media internet dan sosial media atau jejaring sosial. Ini adalah cara modern untuk berpromosi karena memungkinkan orang melihat produk atau jasa yang dipromosikan melalui teknologi terkini seperti ponsel atau laptop. Dengan adanya promosi secara online, diharapkan pemilik atau pelaku usaha UMKM yang ada di Kecamatan Tabanan khususnya di Banjar Adat Denbantas bisa menarik pelanggan dari luar wilayah Denbantas, dan bisa membeli barang kebutuhan yang dapat menunjang keberlangsungan usaha setiap UMKM yang berasal dari wilayah
Banjar Adat Denbantas atau bahkan bisa dari seluruh wilayah di Indonesia.

Pemanfaat teknologi dalam pencatatan keuangan dapat mengefektifkan jalannya usaha UMKM selain itu dapat mengetahui dengan jelas arus kas masuk dan keluar setiap periode dalam usaha. Dengan pemanfaatan Microsfot Excel yang telah disusun Mahasiswa Universitas Mahasaraswati Denpasar untuk pencatatan keungan telah disesuaikan dengen kebutuhan dan akun-akun yang sesuai dengan kegiatan UMKM.

Dari hasil pelatihan yang di lakukan di UMKM Jegeg Bali Tailor, kemampuan dalam pelatihan promosi online dan pelatihan pencatatan laporan keuangan berhasil dilakasanakan melalui observasi, penyuluhan, dan pelatihan.

Berdasarkan pengamatan dan informasi yang diterima dari berbagai pihak, penulis mencoba memberikan saran dan pendapat yang sekitarnya dapat dijadikan bahan pertimbangan yaitu pada kemasan produk yang digunakan dalam pengabdian ini adalah plastik, diharapkan kedepannya bisa memanfaatkan bahan baku ramah lingkungan untuk mengemas produk tanpa menghilangan nilai estetika dan kegunaan dari produk. Kemudian pada bagian promosi dan pencatatan keuangan UMKM dapat memanfaatkan kemajuan ilmu pengetahuan dan teknologi dapat memaksimalkan penjualan produk dengan kegiatan promosi melalui media online serta mengefektifkan pencatatan keuangan dengan penggunaan teknologi.

\section{DAFTAR PUSTAKA}

Aarker, D. (2013). Manajemen Pemasaran Strategis. Edisi 8. Jakarta : Salemba Empat

Anang, S., dkk. (2020). Pedoman Pencegahan Pengendalian Coronavirus Disease (Covid-19). Jakarta: Kementerian Kesehatan RI 
(Diakses pada hari Senin, 31 Agustus 2020 pada link: https://covid19.go.id/storage/app/me dia/Protokol/REV-

05_Pedoman_P2_COVID-

19_13_Juli 2020.pdf)

Astuti, R.P., Kartono, \& Rahmadi. (2020). Pengembangan UMKM melalui Digitalisasi Teknologi Integrasi Permodalan. Ethos: Jurnal Penelitian dan Pengabdian kepada Masyarakat. 8(2), 248-256.

Pakpahan, A.K. (2020). COVID-19 dan Implikasi Bagi Usaha Mikro, Kecil, dan Menengah. Jurnal Ilmiah
Hubungan Internasional. Fakultas lmu Sosial dan Ilmu Politik, Universitas Katolik Parahyangan.

Permana, S.D.H. \& Cendana, M. (2019). Pemanfaatan Sosial Media sebagai Strategi Promosi bagi Sustainability Bisnis UMKM. Ethos: Jurnal Penelitian dan Pengabdian kepada Masyarakat. 7(2), 163-169.

Sukarsih, I., dkk. (2019). Perluasan Jangkauan Pasar Pelaku UMKM di Kota Bandung melalui Implentasi ECommerce. Ethos: Jurnal Penelitian dan Pengabdian kepada Masyarakat. 7(2), 170-17 